\title{
OROBANGHE PANCICII BECK, A NEW SPECIES TO THE FLORA OF SLOVENIA
}

\author{
Igor DAKSKOBLER ${ }^{1}$, Branko VREŠํ ${ }^{2}$ Jürgen PUSCH ${ }^{3}$
}

\begin{abstract}
We describe localities and sites of Orobanche pancicii, a new species of the Slovenian flora. It was recorded in the subalpine belt (1500 to $2000 \mathrm{~m}$ a.s.l.) on forest edges, clearings and on stony grasslands in the Julian Alps and the eastern Karavanke mountains, on the hosts Knautia drymeia, K. longifolia and Scabiosa lucida.

Key words: Orobanche pancicii, flora, new species, the Julian Alps, the Karavanke, Slovenia.

Izvleček

V članku opisujemo nahajališča in rastišča nove vrste slovenske flore, Orobanche pancicii. Našli smo jo v subalpinskem pasu (1500 do $2000 \mathrm{~m}$ nm. v.) na gozdnih robovih, jasah in na kamnitih traviščih v Julijskih Alpah in v vzhodnih Karavankah, na gostiteljih Knautia drymeia, K. longifolia in Scabiosa lucida. Uvajamo tudi slovensko ime Pančičev pojalnik.

Ključne besede: Orobanche pancicii, flora, nova vrsta, Julijske Alpe, Karavanke, Slovenija.
\end{abstract}

\section{INTRODUCTION}

According to the latest data (Strgulc Krajšek 2007, Schneeweiss et al. 2009, Dakskobler et al. 2009) the genus Orobanche in Slovenia comprises 20 species, and three are still expected: Orobanche arenaria (= Phelipanche arenaria), $O$. lucorum and O. pancicii (Strgulc Krajšek 2007: 577-578, Pusch 2009: 49). The knowledge on the occurrence of Orobanche pancicii in Central Europe is relatively new (Pusch 2000, 2009, Pusch \& Günther 2009), as this taxon used to be classified as $O$. reticulata var. viscosa G. Beck or was entirely overlooked. Its distribution range known to date (Pusch 2009: 49) comprises Austria, Bosnia and Herzegovina, Serbia, Hungary, Bulgaria and Greece. Its main differential traits (morphological characteristics) in comparison with the similar species $O$. re- ticulata are a yellow stigma (Figure 2), bidentate sepals (teeth dissimilar) and a distinct smell of carnations (Pusch 2009: 15), whereas O. reticulata has a purple to dark violet stigma and no distinct smell. Host plants of $O$. pancicii are from the genus Knautia ( $K$. drymeia, more rarely $K$. arvensis and $K$. dipsacifolia) and Scabiosa (Pusch 2009: 49), wheares host plants of $O$. reticulata are from the genera Cirsium and Carduus (Pusch 2009, p. 45). In Central Europe Orobanche pancicii grows mainly on forest edges and clearings, on meadows and in tall herb communities from the colline to the subalpine belt (Pusch 2009). This species was detected in several localities during mapping of the flora of the Julian Alps and in the course of our research of larch (Larix decidua) forests in the eastern Karavanke mountains. The localities are presented herein.

\footnotetext{
${ }^{1}$ Institute of Biology, Scientific Research Centre of the Slovenian Academy of Sciences and Arts, Regional unit Tolmin, Brunov drevored 13, SI-5220 Tolmin, Igor.Dakskobler@guest.arnes.si

${ }^{2}$ Institute of Biology, Scientific Research Centre of the Slovenian Academy of Sciences and Arts, Novi trg 2, SI-1000 Ljubljana, BraneVr@zrc-sazu.si

${ }^{3}$ Rottlebener Straße 67, D-06567 Bad Frankenhausen, Germany, J.Pusch@)kyffhaeuser.de
} 


\section{METHODS}

The flora was recorded with established Central-European methods (Ehrendorfer \& Hamann 1965). Field data (floristic records) were entered into the FloVegSi database (Seliškar et al. 2003). This application was subsequently used in the preparation of a distribution map of the studied species in Slovenia (Figure 1). The nomenclature source for the names of vascular plants is the Mala flora Slovenije (Martinčič et al. 2007).

\section{RESULTS}

Below we present the recorded localities of Orobanche pancicii in Slovenia (see also Figure 1). Specimens on all of the localities did have a yellow stigma, but unfortunately the smell of the flowers has not been proven.

9547/4 (UTM 33TUM93): Slovenia, the Julian Alps, the Loška stena ridge, under Mt. Morež,
Zgornji Lepoč (Lašte) below the mountain pass Konjska škrbina, $1980 \mathrm{~m}$ a. s. l., dolomite limestone, subalpine grassland, companion species were also Scabiosa lucida subsp. lucida and Knautia longifolia. Leg. \& det. I. Dakskobler, 19. 8. 2008, confir. J. Pusch, 27. 2. 2010, Herbarium ZRC SAZU (SRC SASA) No. 11595.

9649/3 (UTM 33TVM13): Slovenia, the Julian Alps, Bohinj, on the way from the alp Uskovnica towards Čiprje, near the hunting lodge below the peak Macesnova (Mesnova) glava, dolomite limestone, $1500 \mathrm{~m}$ a.s. l., one of the companion species was also Knautia drymeia. Leg. \& det. I. Dakskobler, B. Vreš, B. Anderle, I. Veber, B. Zupan \& V. Leban, 10. 7. 2008, confir. J. Pusch, 27. 2. 2010, Herbarium ZRC SAZU (SRC SASA) No. 11594; Slovenia, the Julian Alps, Bohinj, on the way from the alp Uskovnica towards Čiprje below the peak Močile, subalpine grassland north-east of the alp Trstje, dolomite limestone, $1500 \mathrm{~m}$ a.s. l., one of the companion species was also Scabiosa lucida subsp. lucida (Figure 3). Leg.

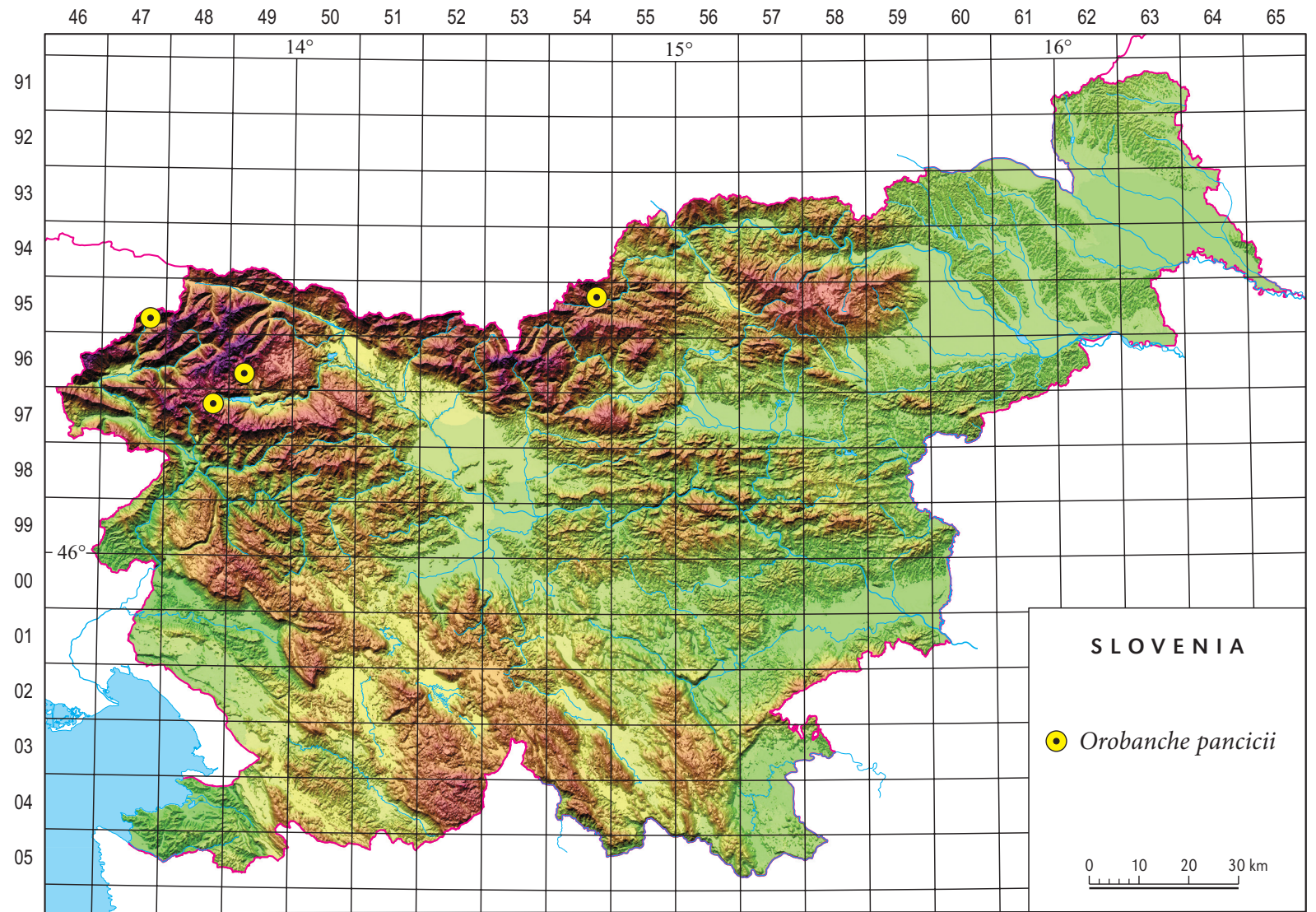

Figure 1: Distribution of Orobanche pancicii in Slovenia.

Slika 1: Razširjenost vrste Orobanche pancicii v Sloveniji. 


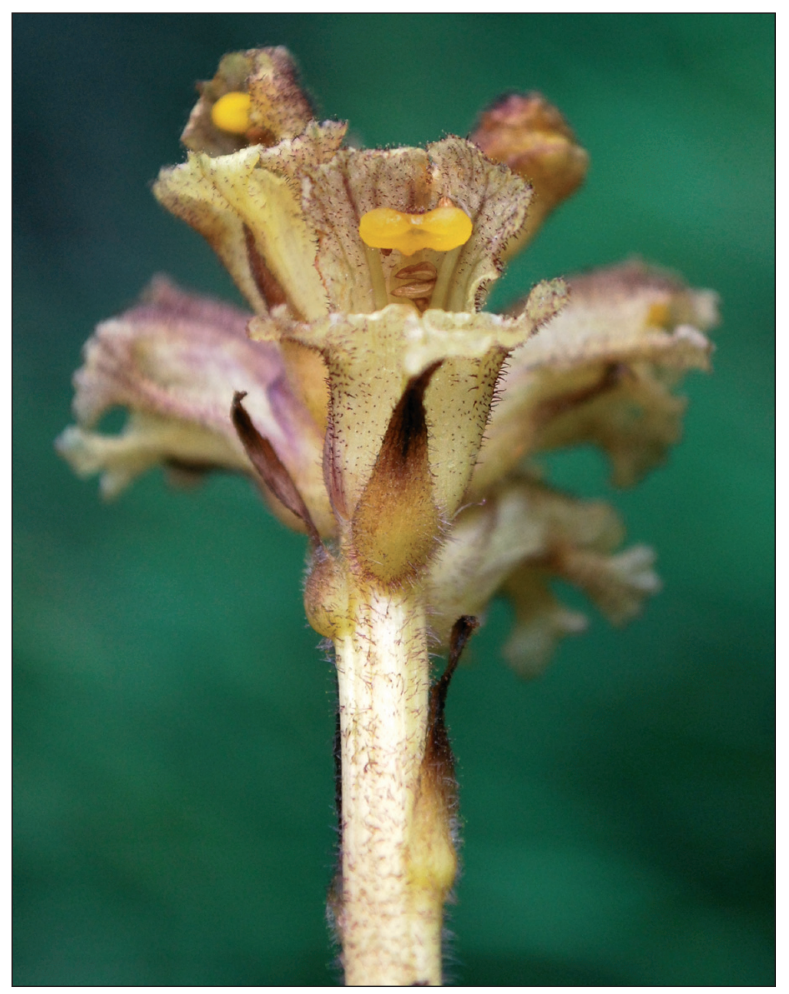

\& det. I. Dakskobler, B. Vreš, B. Anderle, I. Veber, B. Zupan \& V. Leban, 10. 7. 2008, confir. J. Pusch, 27. 2. 2010. (Figure 2).

9748/2 (UTM 33TVM02): Slovenia, the Julian Alps, the Lower Bohinj mountains (Spodnje Bohinjske gore), below the peak Konjski vrh (Konj) on the way to the Konjsko sedlo mountain pass (under Mt. Bohinjski Migovec), $1530 \mathrm{~m}$ a. s. l., dolomite limestone, subalpine stony grassland, companion species were also Scabiosa lucida subsp. stricta and Knautia longifolia. Leg. \& det. I. Dakskobler, I. Veber \& B. Zupan, 29. 7. 2008, confir. J. Pusch, 27. 2. 2010, Herbarium ZRC SAZU (SRC SASA) No. 11593.

9554/2 (UTM 33TVM84): Slovenia, the Karavanke, the Peca ridge, below Mala Peca, $1550 \mathrm{~m}$ a. s. l., limestone, forest edge, one of the compan-

Figure 2: Orobanche pancicii - inflorescence (Photo Branko Vreš).

Slika 2: Orobanche pancicii - socvetje (Foto Branko Vreš).

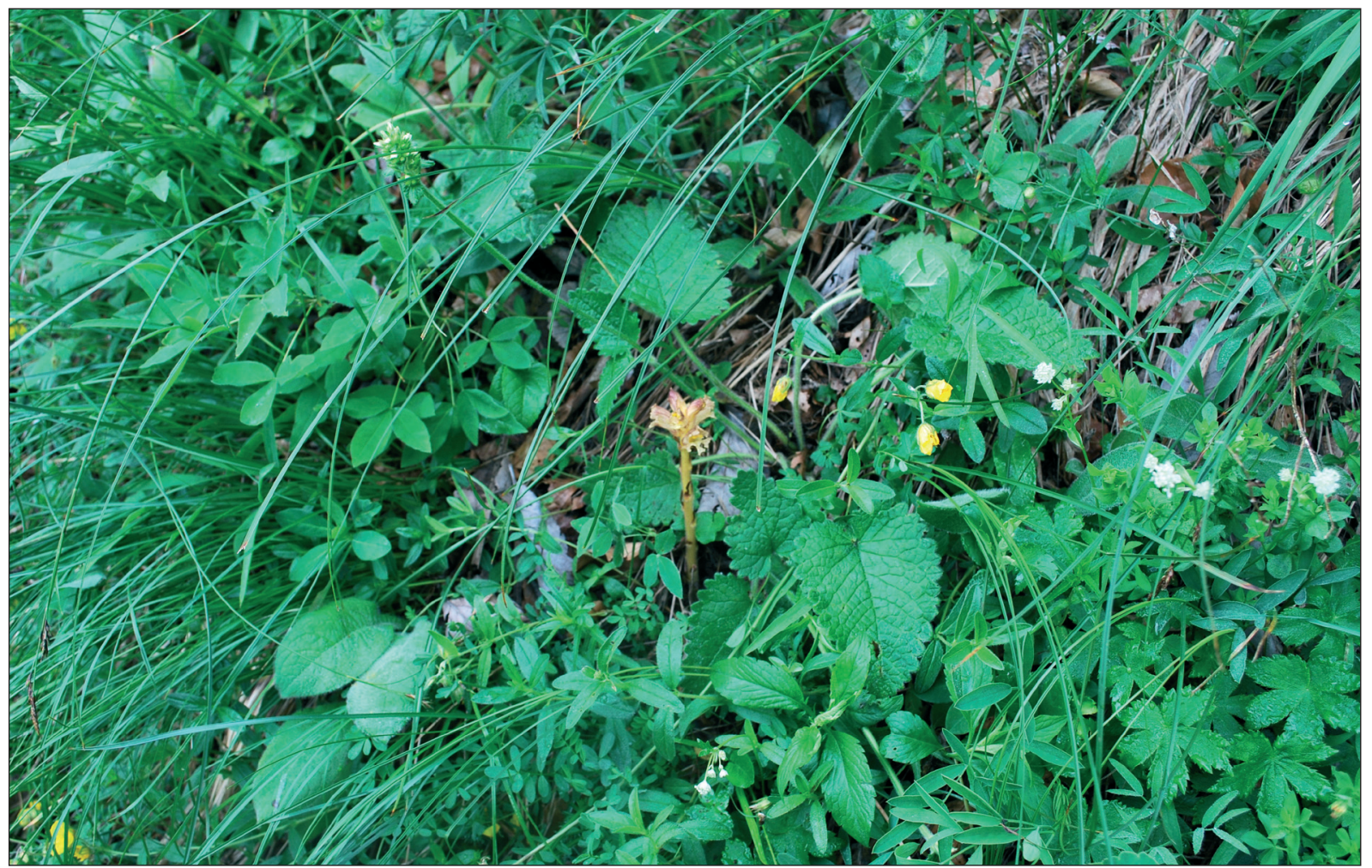

Figure 3: A stand with Orobanche pancicii together with its host plant Scabiosa lucida below the peak Močile (Photo Branko Vreš).

Slika 3: Sestoj z vrsto Orobanche pancicii in njeno gostiteljico bleščečim grintavcem (Scabiosa lucida) pod vrhom Močile (Foto Branko Vreš). 


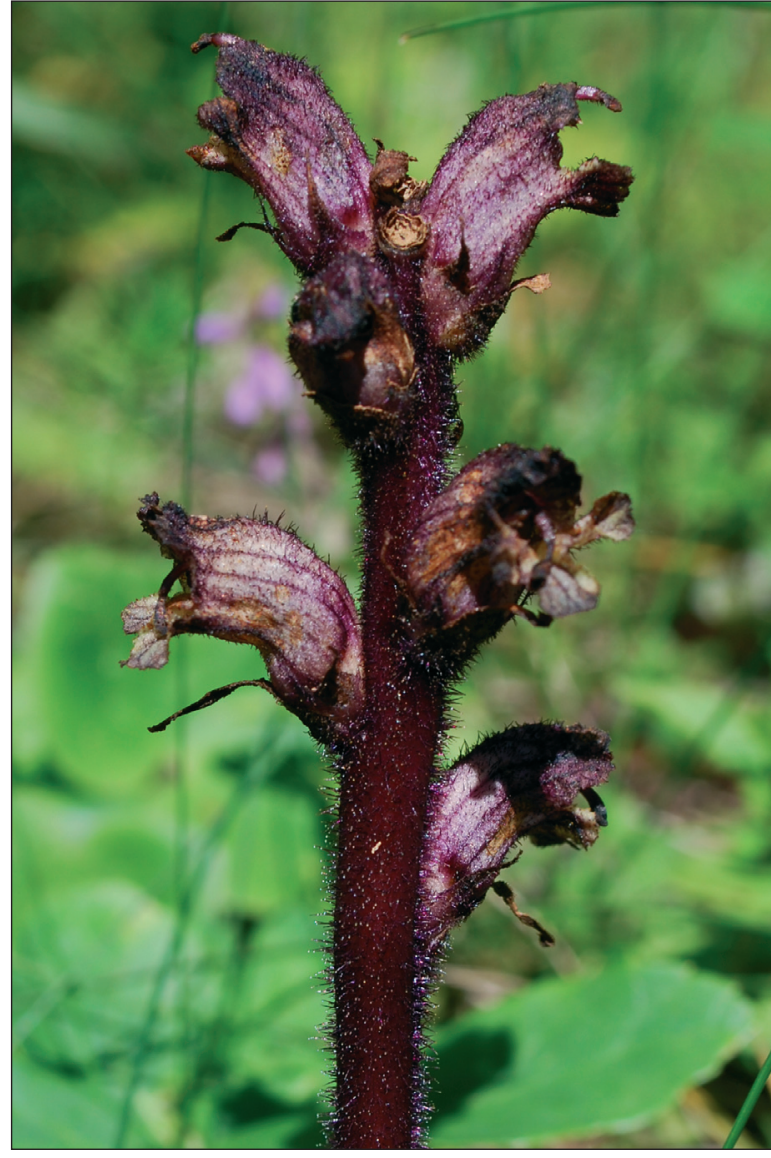

Figure 4: Orobanche pancicii - inflorescence (Photo Branko Vreš).

Slika 4: Orobanche pancicii - socvetje (Foto Branko Vreš).

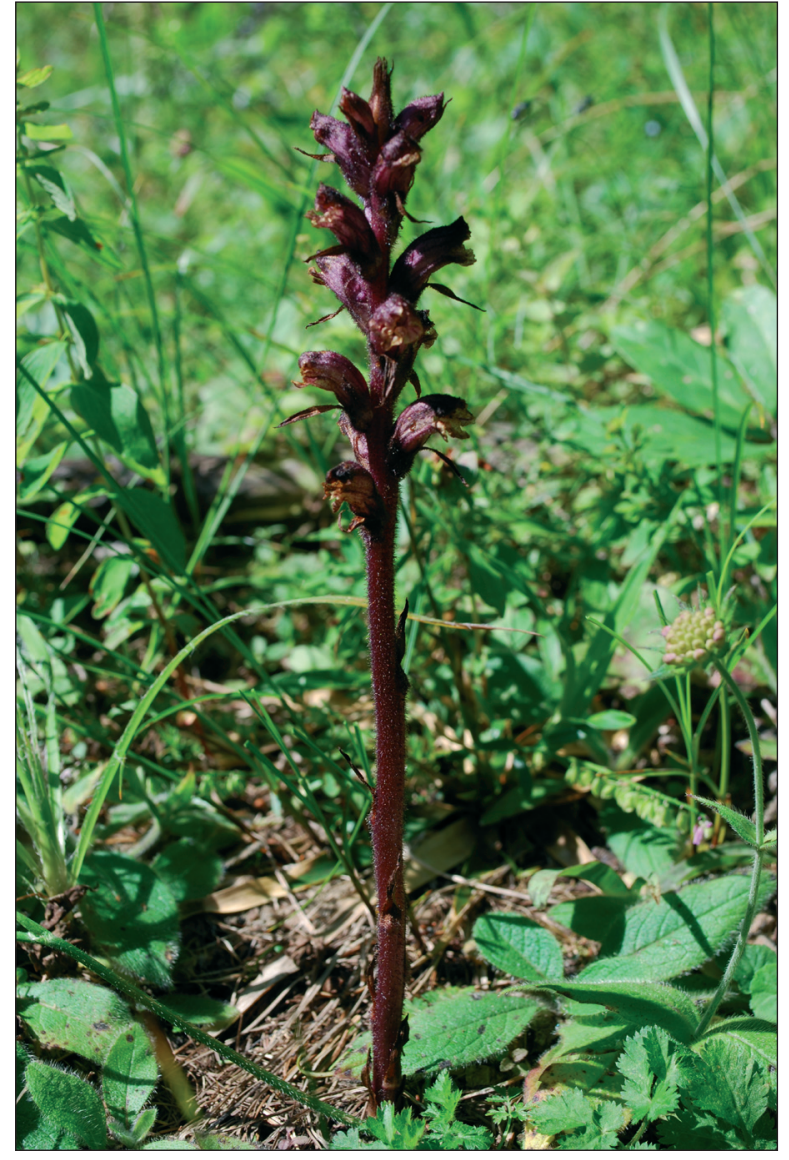

Figure 5: A stand with Orobanche pancicii together with its host plant Knautia drymeia below Mt. Peca (Photo Branko Vreš).

Slika 5: Sestoj z vrsto Orobanche pancicii in njeno gostiteljico ogrskim grabljiščem (Knautia drymeia) na Peci (Foto Branko Vreš).

and Morež, in the latter location almost as high as $2000 \mathrm{~m}$, which is its highest locality known so far in the Alps). The host plant below Mt. Peca was Knautia drymeia (Figure 5), hosts on localities near Uskovnica were Knautia drymeia and Scabiosa lucida (Figure 3), and hosts below Bohinjski Migovec and Morež were Knautia longifolia and Scabiosa lucida.

\section{CONGLUSIONS}

Orobanche pancicii is a new species to the Slovenian flora, expected to occur in Slovenia (Strgulc Krajšek 2007, Pusch 2009). During the field work in the Julian Alps and in the eastern Karavanke we succeeded in recognizing this species 
and thus supplement the knowledge of its distribution area. At the moment its sole localities known in Slovenia are in the subalpine belt (1500 to $2000 \mathrm{~m}$ a.s.l.) and on the sites similar to some known in Austria, e.g. in Carinthia (Pusch 2009). In addition to Knautia drymeia its hosts are also K. longifolia (which was never before reported as the host of $O$. pancicii, see Introduction) and Scabiosa lucida. Because only four localities of $O$. pancicii are known so far in Slovenia, we propose inclusion in the next edition of the Slovenian red data list as a rare species (R), as its habitats are not endangered by the human activities nor by the natural succession. The knowledge on its occurrence in Slovenia will likely increase with further investigations.

\section{POVZETEK}

\section{Orobanche pancicii Beck, nova vrsta v flori Slovenije}

Rod Orobanche po zadnjih podatkih (Strgulc Krajšek 2007, Schneeweiss et al. 2009, Dakskobler et al. 2009) v Sloveniji obsega 20 vrst, pri čemer so pričakovane vsaj še tri: Orobanche arenaria (=Phelipanche arenaria), O. lucorum in O. pancicii (Strgulc Krajšek 2007: 578, Pusch 2009: 49). Vednost o pojavljanju vrste $O$. pancicii v Srednji Evropi je razmeroma nova (Pusch 2000, 2009), prej so ta takson navadno določali kot $O$. reticulata var. viscosa G. Beck, ali pa ga povsem spregledali. Njegova zdaj znana razširjenost (Pusch 2009: 49) obsega Avstrijo, Bosno in Hercegovino, Srbijo, Madžarsko, Bolgarijo in Grčijo. Glavni razlikovalni znaki v primerjavi s podobno vrsto Orobanche reticulata so rumena brazda (slika 2), neenakomerno dvozobi čašni listi in opazen vonj cvetov po nageljčkih (Pusch 2009: 15), medtem ko je brazda pri vrsti $O$. reticulata navadno škrlatna do temno vijoličasta, cvetovi pa brez očitnega vonja. Gostitelji Pančičevega pojalnika so vrste iz rodov Knautia ( $K$. drymeia - slika 5, redkeje $K$. arvensis in $K$. dipsacifolia) in Scabiosa (slika 3), gostitelji mrežastega pojalnika pa vrste iz rodov Cirsium in Carduus. Pančičev pojalnik v Srednji Evropi uspeva predvsem na gozdnih robovih in jasah, na travnikih in v združbah visokih steblik od kolinskega do subalpinskega pasu. V Sloveniji smo ga za zdaj našli le ob zgornji gozdni meji in nad njo (1500 do $2000 \mathrm{~m} \mathrm{~nm}$. v.). Pod Malo Peco v vzhodnih Karavankah (9554/2) raste na jasah in gozdnih robovih $\mathrm{v}$ pionirskem subalpinskem smrekovo-macesnovem gozdu (sliki 4 in 5). Gostitelj je vrsta Knautia drymeia. V bohinjskem delu Julijskih Alp smo ga opazili na podobnih rastiščih pod Macesnovo glavo in v Čiprju (sliki 2 in 3), ob poti iz planine Uskovnica proti planini Trstje (9649/3) ter na kamnitih subalpinskih traviščih pod Bohinjskim Migovcem, ob poti na Konjsko sedlo (9748/2). Na Bovškem uspeva v subalpinsko-alpinskih traviščih pod Konjsko škrbino in Morežem nad dolino Bale (9547/4), skoraj $2000 \mathrm{~m}$ visoko, kar je do zdaj najvišje znano nahajališče v Alpah. Gostitelji v Julijskih Alpah so vrste Knautia drymeia, K. longifolia in Scabiosa lucida. Predlagamo, da vrsto Orobanche pancicii kot redko (R) uvrstimo v Rdeči seznam praprotnic in semenk Slovenije.

\section{ACKNOWLEDGEMENTS}

Ivan Veber, Branko Zupan, Brane Anderle and Vid Leban accompanied us in the field. Andreja Šalamon Verbič translated the article into English. Doc. Dr. Božo Frajman and Dr. Gerald M. Schneeweiss contributed improvements to the text. The research was conducted in the framework of a target research project Natural larch stands in Slovenia (V4-0542), funded by the Slovenian Research Agency and the Ministry of Agriculture, Forestry and Food.

\section{REFERENCES}

Dakskobler, I., Anderle, B. \& Vreš, B. 2009: Novosti v flori Julijskih Alp (severozahodna Slovenija). Folia biologica et geologica 50 (1): 73-119.

Ehrendorfer, F. \& Hamann, U. 1965: Vorschläge zu einer floristischen Kartierung von Mitteleuropa. Ber. Deutsch. Bot. Ges. 78: 35-50.

Martinčič, A., Wraber, T., Jogan, N., Podobnik, A., Turk, B., Vreš, B., Ravnik, V., Frajman, B., Strgulc Krajšek, S., Trčak, B., Bačič, T., Fischer, M. A., Eler, K. \& Surina, B. 2007: Mala flora Slovenije. Ključ za določanje praprotnic in semenk. Četrta, dopolnjena in spremenjena izdaja. Tehniška založba Slovenije, Ljubljana, 967 pp.

Pusch, J. 2000: Orobanche pancicii - Neu für Österreich und für ganz Mitteleuropa. Florist. Rundbr. 34 (2): 27-42. 
Pusch, J. 2009: Gattung Orobanche. In: Wagenitz G. (Herausg.): Gustav Hegi Illustrierte Flora von Mitteleuropa. Band VI, Teil 1A. Lieferung 1: 14-99, Weissdorn-Verlag, Jena.

Pusch, J. \& Günther, K.-F. 2009: Familie Orobanchaceae s. str. Somerwurzgewächse. In: Wagenitz G. (Herausg.): Gustav Hegi Illustrierte Flora von Mitteleuropa. Band VI, Teil 1A. Lieferung 1: 1-13, Weissdorn-Verlag, Jena.

Schneeweiss, G. M., Frajman, B. \& Dakskobler, I. 2009: Orobanche lycoctoni Rhiner, a neglected broomrape species of the Central European flora. Candollea 64 (1): 91-99.

Seliškar, T., Vreš, B. \& Seliškar, A. 2003: FloVegSi 2.0. Računalniški program za urejanje in analizo bioloških podatkov. Biološki inštitut ZRC SAZU, Ljubljana.

Strgulc Krajšek, S. 2007: Orobanchaceae - pojalnikovke. In: Martinčič, A. (ed.): Mala flora Slovenije. Ključ za določanje praprotnic in semenk. Tehniška založba Slovenije, Ljubljana, pp. 573-578. 